\title{
Effect of music combined with swaddling on pain in full-term newborns: randomized clinical trial
}

\author{
Efeito da música combinada com o swaddling na dor em recémnascidos a termo: ensaio clínico randomizado
}

Efecto de la música combinada com swaddling en el dolor en recién nacidos a término: ensayo clínico aleatorizado

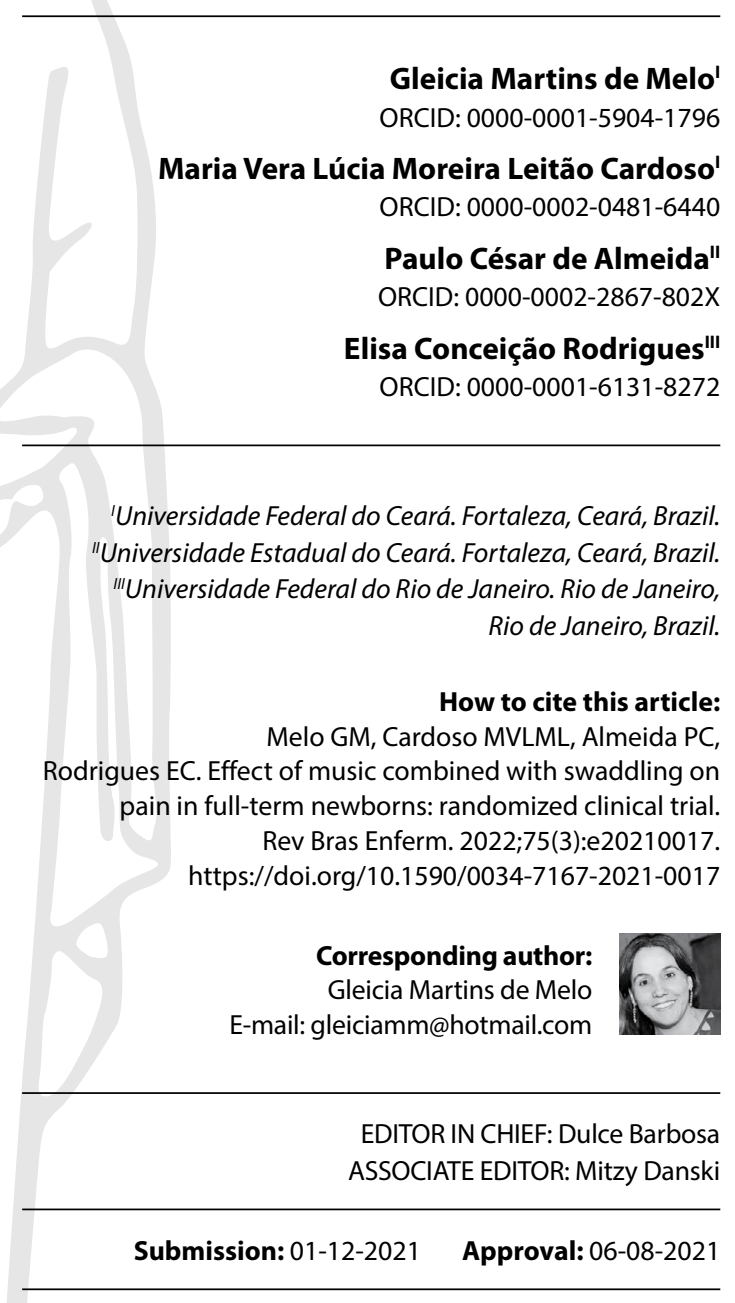

\begin{abstract}
Objectives: to evaluate the effect of music applied within ten and 15 minutes, combined with swaddling, on behavioral (facial action) and physiological (heart rate) responses to pain in fullterm newborns, before and during venipuncture for blood sampling. Methods: a randomized, triple-blind, clinical trial with 52 rooming in infants randomly assigned to four groups of 13: Experimental 1 (music [ten minutes] plus swaddling), Experimental 2 (music [15 minutes] plus swaddling), Control 1 (no music [ten minutes] plus swaddling), and Control 2 (no music [15 minutes] plus swaddling). Pain was measured using the Neonatal Facial Coding System in the basal and procedural moments. Results: experimental 2 group showed high pain absence ( $p$ $<0.05)$; low heart rate mean $(p<0.0001)$ in the basal and procedural (antisepsis, puncture, blood squeezing/aspiration, compression) moments. Conclusions: neonates who listened to 15 minutes of music plus swaddling showed a greater absence of facial pain actions.
\end{abstract}

Descriptors: Music; Pain; Infant, Newborn; Intensive Care; Randomized Controlled Clinical Trial.

\section{RESUMO}

Objetivos: avaliar o efeito da música aplicada em 10 e 15 minutos, combinada ao swaddling, na resposta comportamental à dor (ação facial) e fisiológica (frequência cardíaca) dos recémnascidos a termo, antes e durante a punção venosa para coleta de sangue. Métodos: ensaio clínico randomizado, triplo cego, conduzido em alojamento conjunto com 52 recémnascidos, divididos aleatoriamente em quatro grupos de 13: Experimental 1 (música [10 minutos], swaddling), Experimental 2 (música [15 minutos], swaddling), Controle 1 (sem música [10 minutos], swaddling) e Controle 2 (sem música [15 minutos], swaddling). A dor foi medida utilizando o Neonatal Facial Coding System nos momentos Basal e Procedimento. Resultados: o grupo Experimental 2 mostrou maior ausência de dor $(p<0,05)$; média de frequência cardíaca baixa $(p<0,0001)$ nos momentos Basal e Procedimento (antissepsia, punção, ordenha/aspiração de sangue, compressão). Conclusões: neonatos que ouviram 15 minutos de música mais swaddling mostraram uma maior ausência de ações faciais de dor. Descritores: Música; Dor; Recém-Nascido; Alojamento Conjunto; Ensaio Clínico Controlado Randomizado.

\section{RESUMEN}

Objetivos: evaluar el efecto de la música aplicada en 10 y 15 minutos, combinada con swaddling, en la respuesta comportamental al dolor (mímica facial) y fisiológica (frecuencia cardíaca) de los recién nacidos a término, antes y durante la punción venosa para la extracción de sangre. Métodos: ensayo clínico aleatorizado, triple ciego, realizado en alojamiento conjunto con 52 recién nacidos, dividido aleatoriamente en cuatro grupos de 13: Experimental 1 (música [10 minutos], swaddling), Experimental 2 (música [15 minutos], swaddling), Control 1 (sin música [10 minutos, swaddling) y Control 2 (sin música [15 minutos], swaddling,). El dolor se midió utilizando el Neonatal Facial Coding System en los momentos Basal y Procedimiento. Resultados: el grupo experimental 2 mostró alta ausencia de dolor $(p<0.05)$; media de frecuencia cardíaca baja $(p<0,0001)$ en los momentos Basal y Procedimiento (antisepsia, punción, ordeño/aspiración de sangre, compresión). Conclusiones: recién nacidos que escucharon 15 minutos de música más swaddling mostraron una mayor ausencia de reacciones faciales de dolor. Descriptores: Música; Dolor; Recién Nacido; Alojamiento Conjunto; Ensayo Clínico Controlado Aleatorizado. 


\section{INTRODUCTION}

Pain assessment is subjective, and the newborn is frequently evaluated in both behavioral and physiological responses, such as crying, facial expressions, body expressions, heart rate and respiratory rate, using pain scales ${ }^{(1)}$. The evaluation of behavioral and physiological aspects has the consequence of the best pain measurement tool for newborns being one that has a multi-dimensional model(2).

For this study, the evaluation of facial actions was prioritized using the Neonatal Facial Coding System (NFCS) scale, as well as the basal heart rate, in which full-term neonates were kept on a bench top before venous puncture; and at the time of the procedure, were submitted to antisepsis, puncture, squeezing/ aspirating blood and compression, achieved by way of filming.

There are studies in Brazil ${ }^{(3)}$ and in other countries ${ }^{(4)}$ that investigate further and further measures for the relief of neonatal pain, such as identification, evaluation and treatment that contribute more quickly to better recovery and to care quality ${ }^{(1)}$.

Based on these strategies, non-pharmacological measures are forms of care that should be performed in neonatal units ${ }^{(5)}$, such as comfort, touch, kangaroo care, tucking, nurturance, holding the baby ${ }^{(6)}$, swaddling ${ }^{(6-7)}$, and music ${ }^{(7)}$.

A pilot study involving the use of music for 20 minutes combined to swaddling in health babies showed that full term newborns presented lower pain actions and lower variation in heart rate during venous puncture $(p<0.05)^{(7)}$.

It has been stated that researchers have developed studies on the use of music as a way to relieve neonatal pain. However, according to readings performed by the authors, there is no consensus about the recommended time period for music to be used with a therapeutic purpose for pain relief.

Some Brazilian studies recommend ten minutes of lullaby music, played before arterial puncture ${ }^{(8-9)}, 15$ uninterrupted minutes of classical musical therapy (Mozart), played twice a day, for three consecutive days, one hour after breastfeeding, to evaluate the physiological responses of hospitalized, premature infants ${ }^{(10)}$. Other studies, coming from other countries, highlight 20 minutes of instrumental lullabies, played before the puncture of the calcaneus, continuing for another seven minutes after the procedure ${ }^{(11)}$, continuous, 5 minutes reproductions of recorded lullaby and nursery rhyme music before and up to 30 minutes after painful procedures, at the beginning of hospitalization and two weeks after ${ }^{(12)}$ and one minute of Brahms lullaby before heel lance continuing for up five minutes after the procedure ${ }^{(13)}$.

The relevance of investigating the effect of ten and 15 minutes of music combined with swaddling in pain relief of full-term newborns, in painful procedures, demonstrates implications that may have repercussions on the clinical practice of nursing care, especially in neonatal units and rooming-in facilities. It is believed that with music time periods that are specifically recommended for neonatal pain relief, both nurses and children will benefit: nurses, by seeking increasingly human, holistic care, and newborns, undertaking non-pharmacological measures, with adequate time and proof of pain relief.

The hypothesis of the study is that there is a difference in the behavioral and physiological response to pain in full-term newborns submitted to music interventions, in two time periods of ten and 15 minutes combined to swaddling, before and during, when compared to those full-term newborns in use of swaddling but without music.

\section{OBJECTIVES}

To evaluate the effect of music applied in ten and 15 minutes combined to swaddling on the behavioral (facial action) and physiological (heart rate) response of pain full-term newborns, before and during venous puncture for blood collection.

\section{METHODS}

\section{Ethical aspects}

The Research Ethics Committee Involving Human Beings of the Federal University of Ceará approved the study according to NHC (Brazilian National Health Council) Resolution 466/12. Brazilian Clinical Trial Registry: RBR-8x8v2r.

\section{Study design, place and period}

This is a randomized, triple blind, factorial clinical trial. Randomization was performed using four sealed and numbered opaque envelopes. One of the authors asked the nursing technician, who was on duty and taking care of the newborn, to open one of the envelopes and randomly select intervention to be administered. The draw was held on each of the days in which the collection took place, in the morning and after the nocturnal period. After envelopes were drawn from, a new group was selected with the four interventions (Experimental Group 1, Experimental Group 2, Control Group 1, Control Group 2).

For blinding, the laboratory technicians who collected venous blood, the nurse who analyzed the footage referring to the physiological heart rate responses and the person responsible for the data analysis did not know about the groups and the interventions, thus study was protected from detection bias.

The research was carried out in the rooming-in accommodation of a philanthropic hospital, located in northeast Brazil. The population was composed of newborns, with gestational ages of equal to 37 and less than 42 complete weeks, with indications of needing blood collection for examination (venous puncture), as part of a clinical treatment, from February to December 2017.

\section{Sample, inclusion and exclusion criteria}

Sequence sampling was carried out, consisting of 58 full-term newborns, according to these inclusion criteria: gestational age $\geq 37$ and $<42$ weeks, Apgar scores of $\geq 7$ at 5 ' and normal hearing at neonatal screening, performed by the institution's speech therapist. Exclusion criteria were: newborns using medications and children of whom their nursing mothers were using drugs that influenced in the response pain nociception.

The final sample was composed of 52 newborns distributed in the following groups: Experimental 1 (music, ten minutes + swaddling, $n=13$ ), Experimental 2 (music 15 minutes +swaddling, $n=13$ ), Control 1 (without music, for ten minutes + swaddling, $\mathrm{n}=13$ ) and Control 2 (without music, for 15 minutes + swaddling, $n=13$ ) (Fig. 1). 


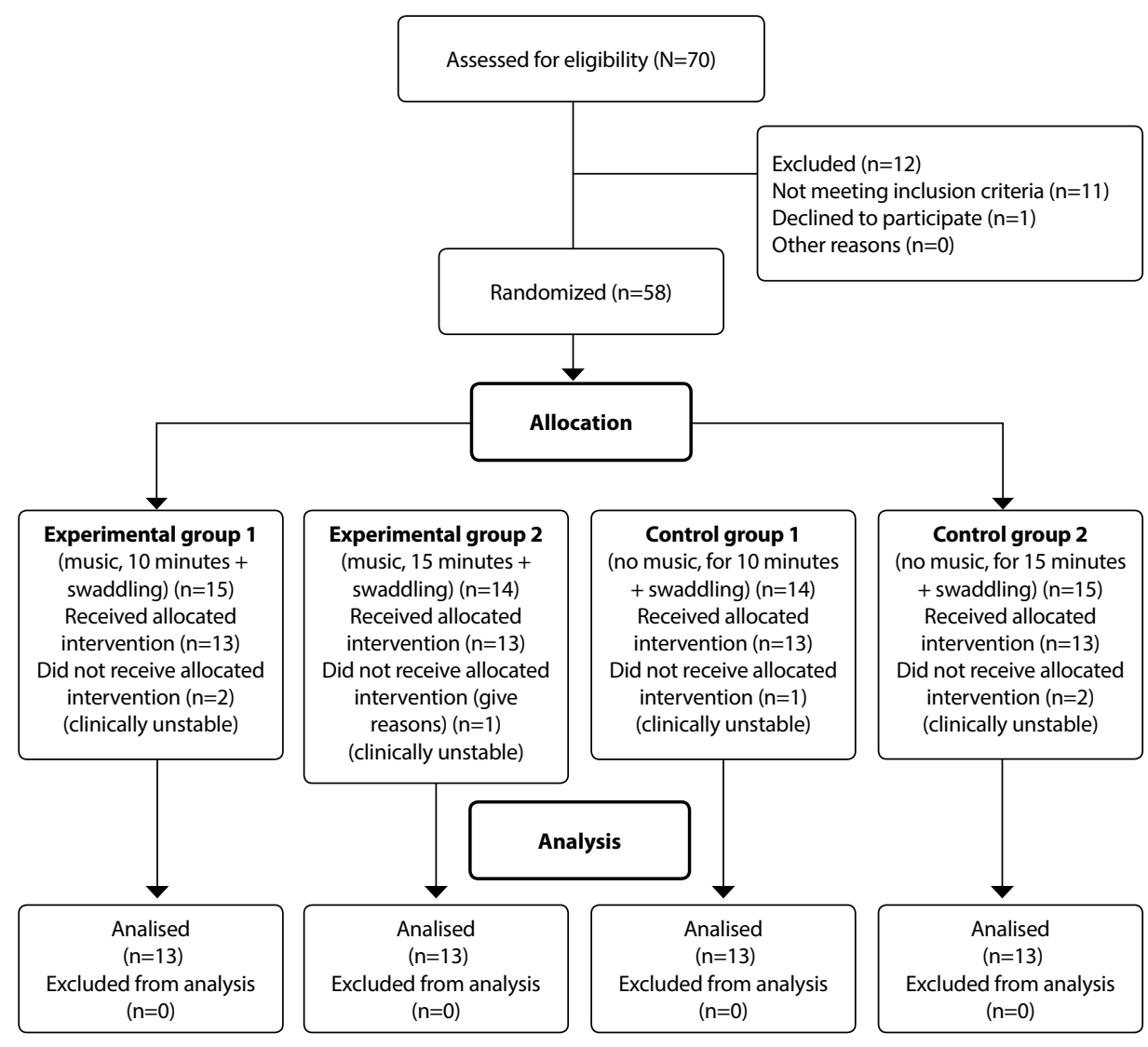

Figure 1 - CONSORT flowchart of the research according to the allocation in the intervention conditions, Fortaleza, Ceará, Brazil, 2018

\section{Study protocol}

Data was collected using three instruments:

1. Identification and Characterization of the Full-Term Newborns, extracted from medical records: gender, type of delivery, previous place of hospitalization, medical diagnosis, gestational age at birth, gestational age in days, hours of life, birth weight (g), head circumference at birth, 5th minute Apgar Score.

2. NFCS ${ }^{(14)}$, includes the presence or absence of five facial manifestations, as follows: brow bulge, eye squeeze, nasolabial furrow, horizontal mouth, taut tongue, with each manifestation of facial action being present, in the observed time segment (second), assigned a point such as: in the interval of the first 20 seconds of the Basal moment; At the time of the procedure, the coding was performed noted for each second for which the procedures lasted: antisepsis, puncture, squeezing/blood aspiration and compression.

3. Physiological Measurements: to evaluate the physiological heart rate responses were used values from 110 to 160 beats/ minute as the normal heart-rate range for the full-term newborn. This variable was recorded continuously, and noted for each second, by means of a cardiac monitor (Polar Model RS 200), adapted and connected by wire cables to two electrodes, both placed in the thorax of the neonate ${ }^{(8)}$. At Basal, the evaluation occurred in blocks of 20 seconds, for a total time of two minutes; at the Procedure time (antisepsis, puncture, squeezing/aspirate blood, compression), coding was performed at each second, according to the duration of venous puncture.

As for the sound stimulus, was confirmed by a speech therapist from the rooming-in locale. If positive, the newborns were referred to the room reserved for the procedures and monitored by the cardiac monitor (Polar RS 200). Due to the institutions routine, before the management of acute neonatal pain, the newborns were contained with the non-pharmacological intervention (swaddling).

The venous puncture was performed on a restraining table by four laboratory technicians that took turns during data collect, each with more than two years of experience. These were made in the left arm as the puncture site (back of the hand or anterior face of the arm). The materials needed for venous puncture were provided by the hospital (procedure gloves, butterfly needle, syringe, tourniquet, swab alcohol, dressing).

Two digital camcorders, supported by tripods, were positioned in the following ways: the first was to face the newborn's face. The other recorded the physiological variables of the cardiac monitor (Polar). An approximate distance of $60 \mathrm{~cm}$, a closet format plan, with zoom feature, without light focus for recording the footage was used. To mark each moment of the filming, we used a manual stopwatch and verbal commands from the researcher to the technician to start the blood collection.

From the beginning of filming, parallel conversations as well as verbalizations directed to the newborn were avoided.

The full-term newborns of Experimental group 1 and 2 used a headset to listen to two instrumental lullabies from the Music Baby collection: Bonne Nuit (Sais-Tu Combien D'étoiles Brillent? and Le Marchand de Sable), were reproduced by means of an MP3 device - digital life player FM. The chosen songs lasted for 2:42 and 3:15 each, played successively.

The songs were played during the time of ten and 15 minutes, after the Basal moment and before the antisepsis procedure for venous puncture, continuing for as long as the Procedure lasted. To avoid contamination between neonates, for each procedure, the headset was previously sanitized with $70 \%$ alcohol and wrapped with polyvinyl chloride film. A volume of 40 decibels was used for music playback, using an MP3 device, evaluated by the Sesmet sector, by sound pressure level meter (decibel meter), being from the INSTRUTEMP brand, with reading in THDL-400.

Swaddling was used in all newborns before the neonatal acute pain management that was begun two minutes before basal moment. 
The Control Group 1 and 2 received swaddling and did not receive musical intervention during the time of ten and 15 minutes, after the basal and procedure moments (antisepsis, puncture, squeezing/aspirate blood, compression). These groups of neonates also used a headset (without music).

\section{Results analysis and statistics}

One of the researches of the study separated and viewed the videos of the behavioral and physiological parameters, to record the beginning and end of each studied moment. This person and a nurse (not involved in the research) analyzed the footage of the behavioral parameter (facial action), after training the NFCS scale, until kappa reliability reached a minimum of $80.0 \%$. The images of the physiological parameter were analyzed by the nurse only.

The data was processed on SPSS 20.0, license number 10101131007. The information from the neonatal, therapeutic, NFCS and heart rate variables were organized by means of tables, with absolute frequencies and percentages, and the means and standard deviations of the quantitative variables were also presented.

In order to compare the proportions of facial actions (NFCS scale), according to the groups, the Chi-Square test was used. For the analysis of the means of heart rates between the four groups and according to the basal and procedure moments, the normality was verified by the Shapiro and Kolmogorov-Smirnov test and the equality of variances by the Levene test, then after by ANOVA. The significance level established was $5 \%(p<0.05)$. The effect size (ES) was analyzed by Cramer's VTest for cross table and Cohen's d for ANOVA test.

\section{RESULTS}

Of the 52 newborns who comprised the sample, males were predominant in Experimental group 1 (53.8\%), Experimental group $2(53.8 \%)$, and females in Control group 1 (61.5\%), Control group 2 (69.2\%); being born by natural delivery, $61.5 \%$ of Experimental group 1, $61.5 \%$ Control group 1, 69.2\% of Control group 2; and caesarean delivery, making up $61.5 \%$ of Experimental group 2.
The average birth weight was $3279.1 \pm 330.3 \mathrm{~g}$ for Experimental group 1, 3336.4 \pm 384.6 for Experimental group 2, 3143.3 \pm 492.3 for Control group 1 and 3256.3 \pm 464.9 for Experimental group 2. Regarding Apgar scores in 5', the value nine stood out for both groups.

Regarding gestational age at birth, the mean was 38.7 to 39.7 weeks. Regarding the newborn's hours of life at the time of venous puncture, the lowest mean and the lowest standard deviation were for Experimental group 2 (13.6 hours and standard deviation 1.9). The mean head circumference at birth ranged from 34.3 to $34.8 \mathrm{~cm}$, considering all investigated neonates.

Regarding the diagnoses, the following were found: adequate for gestational age (90.4\%), risk of neonatal infection (30.8\%), neonatal jaundice (11.5\%), risk of fetal maternal incompatibility $A B O$ (5.8\%), hypoglycemia (5.8\%), large for gestational age (5.8\%), small for gestational age (3.8\%), risk of fetal distress (3.8\%) and auricular appendage (1.9\%). Table 1 describes the distribution of the number of pain absence assessments of facial actions at the basal moment.

The absence of facial pain actions was greater than $79 \%$ in the four groups, with a higher percentage in Experimental Group 2 for all actions ranging from $99.6 \%$ to $100 \%(p<0.0001)$. It was identified that the newborns of Control Group 1 were more active, with a higher percentage in the presence of facial actions. Table 2 identifies the moment of the Antisepsis procedure, puncture, squeezing/blood aspiration and compression in full-term newborns, regarding the absence of facial pain actions in the fourth groups.

For this moment (antisepsis, puncture), the absence of facial pain actions in the four groups, ranges from $23.1 \%$ to $91.3 \%$. In the Experimental Group 2, these values ranged from 80.7 to 91.3 , in both the antisepsis and puncture procedures $(p<0.0001)$.

In the squeezing/blood aspiration and compression moments, the number of observations prevailed in Experimental Group 2 in the five manifestations of facial actions in the absence of facial actions, ranging from 64.3 to $82 \%$; while in the other three groups, the percentages ranged from $25.5 \%$ to $70.1 \%$. The data from Table 3 show the means and standard deviations of the physiological heart rate indicator in terms of mean and standard deviation, during the moments of data collection in the four groups.

Table 1 - Distribution of number of evaluations, in basal moment, regarding the presence and absence of facial pain actions of full-term newborn by Neonatal Facial Coding System, Fortaleza, Ceará, Brazil, 2018

\begin{tabular}{|c|c|c|c|c|c|}
\hline \multirow[b]{2}{*}{ Facial actions } & \multirow[b]{2}{*}{$\begin{array}{c}\text { Experimental } 1 \\
n^{\circ}(\%)\end{array}$} & \multicolumn{2}{|c|}{ Group } & \multirow[b]{2}{*}{$\begin{array}{c}\text { Control } 2 \\
n^{\circ}(\%)\end{array}$} & \multirow[b]{2}{*}{$\begin{array}{c}\text { p-value } \\
\text { (SE)** }\end{array}$} \\
\hline & & $\begin{array}{c}\text { Experimental } 2 \\
n^{\circ}(\%)\end{array}$ & $\begin{array}{c}\text { Control } 1 \\
n^{\circ}(\%)\end{array}$ & & \\
\hline \multicolumn{6}{|l|}{ Brow bulge } \\
\hline Presence & $21(8.1)$ & $1(0.4)$ & $54(20.8)$ & $9(3.5)$ & $<0.0001$ \\
\hline Absence & $239(91.9)$ & $259(99.6)$ & $206(79.2)$ & $251(96.5)$ & $(0.2836)$ \\
\hline \multicolumn{6}{|l|}{ Narrow eyes } \\
\hline Presence & $20(7.7)$ & $1(0.4)$ & $54(20.8)$ & $6(2.3)$ & $<0.0001$ \\
\hline Absence & $240(92.3)$ & $259(99.6)$ & $206(79.2)$ & $254(97.7)$ & $(0.297)$ \\
\hline \multicolumn{6}{|c|}{ Deepened nasolabial furrow } \\
\hline Presence & $20(7.7)$ & 0 & $54(20.8)$ & $5(1.9)$ & $<0.0001$ \\
\hline Absence & $240(92.3)$ & $260(100)$ & $206(79.2)$ & $255(98.1)$ & $(0.3063)$ \\
\hline \multicolumn{6}{|c|}{ Horizontal Opened mouth } \\
\hline Presence & $20(7.7)$ & 0 & $52(20)$ & $7(2.8)$ & $<0.0001$ \\
\hline Absence & $240(92.3)$ & $260(100)$ & $208(80)$ & $247(97.2)$ & $(0.289)$ \\
\hline \multicolumn{6}{|l|}{ Taut tongue } \\
\hline Presence & $20(7.7)$ & 0 & $47(18.1)$ & 0 & $<0.0001$ \\
\hline Absence & $240(92.3)$ & $260(100)$ & $213(81.9)$ & $254(100)$ & $(0.3014)$ \\
\hline
\end{tabular}


Table 2 - Distribution of the number of evaluations, in the procedure moment (antisepsis, puncture, squeezing/blood aspiration and compression), regarding the presence and absence of facial pain actions and groups, Fortaleza, Ceará, Brazil, 2018

\begin{tabular}{|c|c|c|c|c|c|}
\hline Facial actions & $\begin{array}{c}\text { Experimental Group } 1 \\
\mathbf{n}^{\circ}(\%)\end{array}$ & $\begin{array}{c}\text { Experimental Group } 2 \\
n^{\circ}(\%)\end{array}$ & $\begin{array}{c}\text { Control Group } 1 \\
n^{\circ}(\%)\end{array}$ & $\begin{array}{c}\text { Control Group } 2 \\
n^{\circ}(\%)\end{array}$ & $\begin{array}{c}p \text { value }{ }^{*} \\
(\mathrm{SE})^{* *}\end{array}$ \\
\hline \multicolumn{6}{|l|}{ Antisepsis } \\
\hline \multicolumn{6}{|l|}{ Brow bulge } \\
\hline Presence & 84 (58.7) & $41(18,8)$ & 94 (60.6) & $8(71.9)$ & $<0.0001$ \\
\hline Absence & $59(41.3)$ & $177(81.2)$ & $61(39.4)$ & $34(28.1)$ & $(0.4316)$ \\
\hline \multicolumn{6}{|l|}{ Narrow eyes } \\
\hline Presence & 85 (59.4) & $42(19.3)$ & 94 (60.6) & 87 (71.9) & $<0.0001$ \\
\hline Absence & $58(40.6)$ & $176(80.7)$ & $61(39.4)$ & $34(28.1)$ & $(0.4288)$ \\
\hline \multicolumn{6}{|c|}{ Deepened nasolabial furrow } \\
\hline Presence & $86(60.1)$ & 27 (12.4) & $94(60.6)$ & $84(69.4)$ & $<0.0001$ \\
\hline Absence & $57(39.9)$ & $191(87.6)$ & 61 (39.4) & $37(30.6)$ & $(0.4863)$ \\
\hline \multicolumn{6}{|c|}{ Horizontal Opened mouth } \\
\hline Presence & $86(60.1)$ & $19(8.7)$ & $90(58.1)$ & $80(66.1)$ & $<0.0001$ \\
\hline Absence & $57(39.9)$ & $199(91.3)$ & $65(41.9)$ & $41(33.9)$ & $(0.5042)$ \\
\hline \multicolumn{6}{|l|}{ Taut tongue } \\
\hline Presence & $34(23.8)$ & $19(8.7)$ & $79(51)$ & $68(56.2)$ & $<0.0001$ \\
\hline Absence & $109(76.2)$ & $199(91.3)$ & $76(49)$ & $53(43.8)$ & $(0.4305)$ \\
\hline \multicolumn{6}{|l|}{ Puncture } \\
\hline \multicolumn{6}{|l|}{ Brow bulge } \\
\hline Presence & $8(61.5)$ & $2(15,4)$ & $10(76,9)$ & $10(76,9)$ & 0.004 \\
\hline Absence & $5(38.5)$ & $11(84,6)$ & $3(23,1)$ & $3(23,1)$ & $(0.5105)$ \\
\hline \multicolumn{6}{|l|}{ Narrow eyes } \\
\hline Presence & $8(61.5)$ & $2(15,4)$ & $10(76,9)$ & $10(76,9)$ & 0.004 \\
\hline Absence & $5(38.5)$ & $11(84.6)$ & $3(23.1)$ & $3(23.1)$ & $(0.5105)$ \\
\hline \multicolumn{6}{|c|}{ Deepened nasolabial furrow } \\
\hline Presence & $8(61.5)$ & $2(15.4)$ & $10(76.9)$ & $10(76.9)$ & 0.004 \\
\hline Absence & $5(38.5)$ & $11(84.6)$ & $3(23.1)$ & $3(23.1)$ & $(0.5105)$ \\
\hline \multicolumn{6}{|c|}{ Horizontal Opened mouth } \\
\hline Presence & $8(61.5)$ & $2(15.4)$ & $9(69.2)$ & $10(76.9)$ & 0.007 \\
\hline Absence & $5(38.5)$ & $11(84.6)$ & $4(30.8)$ & $3(23.1)$ & $(0.482)$ \\
\hline \multicolumn{6}{|l|}{ Taut tongue } \\
\hline Presence & $5(38.5)$ & $2(15.4)$ & $8(61.5)$ & $7(53.8)$ & 0.085 \\
\hline Absence & $8(61.5)$ & $11(84.6)$ & $5(38.5)$ & $6(46.2)$ & $(0.3831)$ \\
\hline \multicolumn{6}{|c|}{ Squeezing/blood aspiration } \\
\hline \multicolumn{6}{|l|}{ Brow bulge } \\
\hline Presence & $481(64.5)$ & $375(26,8)$ & $515(64,6)$ & $661(74,5)$ & $<0.0001$ \\
\hline Absence & $265(35.5)$ & $1022(73,2)$ & $282(35,4)$ & $226(25,5)$ & $(0.4065)$ \\
\hline Narrow eyes & & & & & \\
\hline Presence & $476(63.8)$ & 391 (28) & $526(62,5)$ & $649(73,2)$ & $<0.0001$ \\
\hline Absence & $270(36.2)$ & $1006(82)$ & $316(37,5)$ & $238(26,8)$ & $(0.3805)$ \\
\hline Deepened $n$ & & & & & \\
\hline Presence & $451(60.5)$ & $330(23.6)$ & $550(65.3)$ & $640(72.2)$ & $<0.0001$ \\
\hline Absence & $295(39.5)$ & $1067(76.4)$ & $282(34.7)$ & $247(27.8)$ & $(0.4198)$ \\
\hline Horizontal O & & & & & \\
\hline Presence & $422(56.6)$ & $293(21)$ & $524(62.2)$ & 649 (73.2) & $<0.0001$ \\
\hline Absence & $324(43.4)$ & $1104(79)$ & $318(37.8)$ & $238(26.8)$ & $(0.432)$ \\
\hline Taut tongue & & & & & \\
\hline Presence & $228(29.9)$ & $323(23.1)$ & 465 (55.2) & 477 (53.8) & $<0.0001$ \\
\hline Absence & $535(70.1)$ & $1074(76.9)$ & $377(44.8)$ & $410(46.2)$ & $(0.3003)$ \\
\hline Compression & & & & & \\
\hline Brow bulge & & & & & \\
\hline Presence & $295(47.2)$ & $128(21.2)$ & $379(70.3)$ & $298(42.1)$ & $<0.0001$ \\
\hline Absence & $330(52.8)$ & $477(78.8)$ & $160(29.7)$ & $410(57.9)$ & $(0.3377)$ \\
\hline Narrow eyes & & & & & \\
\hline Presence & $308(49.3)$ & $216(35.7)$ & $340(66)$ & $324(45.8)$ & $<0.0001$ \\
\hline Absence & $317(50.7)$ & $389(64.3)$ & $175(34)$ & $384(54.2)$ & $(0.2071)$ \\
\hline Deepened $\mathrm{n}$ & & & & & \\
\hline Presence & 306 (49) & $200(33.1)$ & $342(66.4)$ & $232(32.8)$ & $<0.0001$ \\
\hline Absence & $319(51)$ & $405(66.9)$ & $173(33.6)$ & $476(67.2)$ & $(0.2685)$ \\
\hline Horizontal $\mathrm{O}$ & & & & & \\
\hline Presence & 306 (49) & $187(30.9)$ & $313(60.8)$ & $223(31.5)$ & $<0.0001$ \\
\hline Absence & $319(51)$ & $418(69.1)$ & $202(39.2)$ & $485(68.5)$ & $(0.247)$ \\
\hline Taut tongue & & & & & \\
\hline Presence & $194(34.4)$ & $156(25.8)$ & $295(57.3)$ & $183(25.8)$ & $<0.0001$ \\
\hline Absence & $370(65.6)$ & 449 (74.2) & $220(42.7)$ & 525 (74.2) & $(0.2601)$ \\
\hline
\end{tabular}


Table 3 - Comparison of the means of the newborns' heart rate during the moments of data collection regarding groups, Fortaleza, Ceará, Brazil, 2018

\begin{tabular}{|c|c|c|c|c|c|}
\hline Moments & $\begin{array}{c}\text { Experimental Group } 1 \\
\overline{\mathrm{X}}_{ \pm \mathrm{SD}}\end{array}$ & $\begin{array}{c}\text { Experimental Group } 2 \\
\overline{\mathbf{X}}_{ \pm S \mathrm{SD}}\end{array}$ & $\begin{array}{c}\text { Control Group } 1 \\
\overline{\mathbf{X}} \pm \text { SD }\end{array}$ & $\begin{array}{c}\text { Control Group } 2 \\
\overline{\mathrm{X}} \pm \text { SD }\end{array}$ & $p$ value* \\
\hline Basal & $130.5 \pm 21.4$ & $123.6 \pm 12.8$ & $135.5 \pm 24.2$ & $131.1 \pm 17.5$ & $<0.0001$ \\
\hline \multicolumn{6}{|l|}{ Procedure } \\
\hline Antisepsis & $148.9 \pm 13.6$ & $129.1 \pm 18.4$ & $149.6 \pm 19.8$ & $141.5 \pm 23.3$ & $<0.0001$ \\
\hline Puncture & $152.1 \pm 18$ & $131.1 \pm 18.5$ & $148.9 \pm 22.8$ & $145 \pm 26,1$ & 0.082 \\
\hline Squeezing/ Blood aspiration & $154.8 \pm 21.1$ & $140 \pm 23.9$ & $152.9 \pm 22.3$ & $159.2 \pm 25.7$ & $<0.0001$ \\
\hline Compression & $153.6 \pm 37.9$ & $149.4 \pm 29.2$ & $150.1 \pm 21.1$ & $150.1 \pm 30.8$ & 0.073 \\
\hline
\end{tabular}

The full-term newborns of Experimental Group 1, Experimental Group 2, Control Group 1 and Control Group 2 presented mean heart rates within the normal range, however, with statistically significant difference between the groups at basal, with lower mean in Experimental Group $2(p<0.0001)$. At the procedure time, the lowest mean was also in Experimental Group 2, in antisepsis $(p<0.0001)$ and squeezing/blood aspiration $(p<0.0001)$. The peak heart rate occurred at the squeezing time, among the newborns of the four allocation groups, while in Experimental Group 2 it was in compression time.

\section{DISCUSSION}

The main finding was that 15 minutes of music from the recorded lullaby, once a day, at an intensity of $40 \mathrm{~dB}$ combined to swaddling, at the basal and procedure moments, was effective when compared to ten minutes of music combined to swaddling.

A randomized clinical trial with premature infants aimed to examine whether combined music and touch intervention (CMT) is an effective pain management method for premature infants during the painful procedures performed in a neonatal unit; infants in the control group without intervention; infants in the experimental group with CMT. Premature Infant Pain Profile (PIPP) was used to measure pain. The mean PIPP scores were 11.17 \pm 0.91 and $12.14 \pm 0.46$ (control vs. experimental), respectively, at the beginning of the hospitalization. After 2 weeks, the PIPP score in the control group had significantly increased $(\mathrm{t}=2.573 ; P<0.05)$ and that in the experimental group had significantly decreased $(\mathrm{t}=2.216 ; P<0.05)$. It was not identified significant difference between the two groups at the beginning, however, two weeks later the experimental group had a significantly lower score than the control group $(10.50 \pm 0.85 \text { vs } 13.00 \pm 0.46 \text {, respectively; } P<0.05)^{(12)}$.

Another randomized clinical trial conducted in Iran evaluated the effect of music therapy (for 15 minutes) on the physiological (heart rate, oxygen saturation) and behavioral (NFCS) pain responses of preterm infants during and after blood sampling by arterial puncture, noting that recorded music, administered once a day, at an intensity of 45-60 dB was effective compared to the Control Group (without music), heart rate (needle removal $p=0.022$ and in the first five minutes after the puncture $p=0.005$ ); in the sleep-wake state (five minutes before the puncture $p=0.044$, during the puncture $p=0.045$, in the first five minutes after the puncture $p=0.002$ and five minutes after the puncture $p=0.005$ ); facial expressions (in the first five minutes after puncture $p=0.001)^{(15)}$.

In a pilot study involving neonates who listened to music combined with the swaddling technique had less pain actions during the venous puncture than those exposed only to swaddling. For the procedure (antisepsis and puncture), there was difference for all facial actions studied $(p<0.05)$ and odds ratio for absence of pain reaction was 17.1 times higher, at the time of antisepsis for experimental group (both music and swaddling) ${ }^{(7)}$.

Another randomized clinical trial, with 30 newborns from a neonatal intensive care unit of a Tehran hospital, aimed to evaluate the effect of maternal voice on pain in full-term newborns admitted to the neonatal intensive care unit, which listened to the sound therapy recorded for a time of ten minutes before, during and then for ten minutes after arterial puncture, at an intensity of 50-60 dB, by means of two speakers (200V Sony) placed at a distance of $20 \mathrm{~cm}$ from the newborn's head, identifying, by means of the Neonatal Infant Pain Scale that the maternal voice reduced the pain of newborns during arterial puncture $(p<0.005)^{(16)}$.

Referring to the Basal moment, there was a higher percentage of absence of facial actions from pain for brow bulge (99.6\%), eye squeeze (99.6\%), nasolabial furrow (100\%), horizontal mouth (100\%) and taut tongue (100\%), for Experimental Group 2, when compared to the other groups. On the other hand, a randomized, double-blind clinical trial in a neonatal intermediate unit of a public hospital in Brazil, identified that preterm newborns in the experimental group (music) anticipated pain in preparation for puncture compared to the value found at basal, through NFCS, in relation to the Control Group (glucose $25 \%)^{(9)}$.

At the Procedure moment (antisepsis, puncture, squeezing/ blood aspiration, compression), the quantitative brow bulge, eye squeeze, nasolabial furrow, horizontal mouth and taut tongue were smaller in Experimental Group $2(p<0.05)$.

In an experimental study, carried out in the neonatal intensive care unit of a hospital in Italy, the objective was to determine the effect of music by Mozart (Violin Concerto No. 3 in G major, K. 216, II. Adagio), in the puncture of the calcaneus of 42 premature infants, who listened to music for two minutes before, during and after the puncture for a total period of five minutes, at an intensity of about $65-70 \mathrm{~dB}$, by means of speakers placed inside the incubator, about $30 \mathrm{~cm}$ from the newborns' ears. The results showed a significantly lower score in the mean of the Premature Infant Pain Profile scores for the experimental group (with music) $(5.1 \pm 1.8)(p=0.000)$, compared to the control group (without music) $(14.3 \pm 4.3)^{(17)}$.

Regarding physiological heart rate indicators, newborns from both allocation groups presented values within the normal range at all studied moments. In Experimental group 2 (15 minutes of music) there was greater stability of heart rate, with lower means than in newborns from the other groups, with statistical 
significance $(p<0.05)$, in the Basal and Procedural moments at puncture Procedural moment $(p=0.082)$ and the compression moments $(p=0.073)$, there was no statistically significant difference when comparing the four allocation groups. There was a peak heart rate at the Procedural moment (milking) among the full-term newborns of Experimental group 1, Control group 1 and Control group 2, while in Experimental group 2, it was at the Procedure moment (compression).

Similarly, found a statistically significant difference between the heart rate of premature infants when they investigated the effects of recorded lullabies and maternal voice recorded for 30 minutes for 14 consecutive days, with an intensity of 55-66 $\mathrm{dB}$. Both musical interventions led to a decrease in heart rate $(p$ $<0.001$ ) during and after musical intervention, when compared to the control group (without acoustic stimulation) ${ }^{(18)}$.

A double-blind, randomized, controlled trial was carried out in the NICUs of 2 general public hospitals in Spain with 17 healthy preterm infants. It evaluated the effect of a relaxing music therapy intervention on respiratory rate, systolic and diastolic blood pressure, and heart rate. The results showed that a relaxing music in the computational Melomics (intensity $30 \mathrm{~dB}$ ) lasted 20 minutes, 3 times a day for 3 consecutive days, the heart rate was higher in the control group (without intervention) $(F 1,11=5.09, \mathrm{P}=$ .045 , npartial $=0.32$ ) than neonates exposed to music therapy (experimental group) $^{(19)}$.

Differently, in the randomized clinical trial, no significant difference was found between the heart rate of preterm newborns who were allocated to the lullaby group, the silence group (unplayed music) and the control group (care before $(p=0.33)$, at the end of the 20-minute intervention $(p=0.41)$ and in the ten minutes after the intervention $(p=0.057)$. The lullaby was played at an intensity of 55-60 dB, through headphones ${ }^{(20)}$.

\section{Limitations of the study}

The following are limitations: a) the reduced sample size, due to the demand for rooming in; $b$ ) heart rate data had been blinded only to the main researcher; and c) the venous puncture collection was performed by four different laboratory technicians, this may have interfered in the response of neonates to pain.

\section{Contributions of the study}

It is believed this research contributed as innovative way for clarification of important aspects related to pain bio-behavioral reactivity of full-term newborns submitted to venous puncture, with pain minimization and use of non-pharmacological measures like music during 15 minutes, therefore being recommended for use in the clinical and academic practice. However, other studies involving high samples must to be encouraged.

\section{CONCLUSIONS}

In view of the results presented, it was proved that full-term newborns submitted to the Experimental Group 2 before and during venous puncture for blood collection showed a greater absence of facial actions.

The hypothesis was proven that there is a difference in the behavioral and physiological pain responses of full-term newborns submitted to music intervention (for ten minutes and 15 minutes) combines to swaddling, before and during venous puncture for blood collection.

\section{FUNDING}

This study was financed in part by the Coordenação de Aperfeiçoamento de Pessoal de Nível Superior - Brasil (CAPES) - Finance Code 001.

\section{SUPPLEMENTARY MATERIAL}

http://www.repositorio.ufc.br/bitstream/riufc/33944/1/2018_ tese_gmmelo.pdf

https://ensaiosclinicos.gov.br/rg/RBR-8x8v2r

\section{REFERENCES}

1. Christoffel MM, Castral TC, Daré MF, Montanholi LL, Gomes ALM, Scochi CGS. Attitudes of healthcare professionals regarding the assessment and treatment of neonatal pain. Esc Anna Nery. 2017;21(1). https://doi.org/10.5935/1414-8145.20170018

2. Fitri SYR, Lusmilasari L, Juffrie M. The Indonesian version of the Premature Infant Pain Profile-Revised: translation and adaptation of a neonatal pain assessment. Int J Nurs Sci. 2019;6(4):439-44. https://doi.org/10.1016/j.ijnss.2019.06.010

3. Melo GM, Cardoso MVLML. Non-pharmacological measures in preterm newborns submitted to arterial puncture. Rev Bras Enferm. 2017;70(2):317-25. https://doi.org/10.1590/0034-7167-2016-0003

4. Lago P, Frigo AC, Baraldi E, Pozzato R, Courtois E, Rambaud J, et al. Sedation and analgesia practices at Italian neonatal intensive care units: results from the EUROPAIN study. Ital J Pediatr. 2017;43(1):26. https://doi.org/10.1186/s13052-017-0343-2

5. Gomes PPS, Lopes APA, Santos MSN, Façanha SMA, Silva AVS, Chaves EMC. Non-pharmacological measures for pain relief in venipuncture in newborns: description of behavioral and physiological responses. Braz J Pain. 2019;2(2). https://doi.org/10.5935/2595-0118.20190026

6. Sposito NPB, Rossato LM, Bueno M, Kimura AF, Costa T, Guedes DMB. Assessment and management of pain in newborns hospitalized in a Neonatal Intensive Care Unit: a cross-sectional study. Rev Latino-Am Enfermagem. 2017;25:e2931. https://doi. org/10.1590/1518-8345.1665.2931

7. Viana TRF, Melo GM, Cardoso MVLML, Almeida PC, Oliveira LM, Santos DAS. Pain in full term newborns submitted to music and swaddling during venipunctures. Rev Rene. 2020;21:e43904. https://doi.org/10.15253/2175-6783.20202143904 
8. Cardoso MVLML, Farias LM, Melo GM. Music and $25 \%$ glucose pain relief for the premature infant: a randomized clinical trial. Rev Latino-Am Enfermagem. 2014;22(5):810-8. Available from: https://doi.org/10.1590/0104-1169.0029.2484

9. Melo GM, Cardoso MVLML. Pain in preterm newborns submitted to music and 25\% glucose intervention. Rev Rene. 2017;18(1):3-10. https:// doi.org/10.15253/2175-6783.2017000100002

10. Silva CM, Cação JMR, Silva KCS, Marques CF, Merey LSF. Physiological responses of preterm newborn infants submitted to classical music therapy. Rev Paul Pediatr. 2013;31(1):30-6. https://doi.org/10.1590/S0103-05822013000100006

11. Shah SR, Kadage S, Sinn J. Trial of music, sucrose, and combination therapy for pain relief during heel prick procedures in neonates. J Pediatr. 2017;190:153-8.e2. https://doi.org/10.1016/j.jpeds.2017.08.003

12. Qiu J, Jiang Y, Li F, Tong Q, Rong H, Cheng R. Effect of combined music and touch intervention on pain response and $\beta$-endorphin and cortisol concentrations in late preterm infants. BMC Pediatr. 2017;17:38. https://doi.org/10.1186/s12887-016-0755-y

13. Uematsu $\mathrm{H}$, Sobue I. Effect of music (Brahms lullaby) and non-nutritive sucking on heel lance in preterm infants: a randomized controlled crossover trial. Paediatr Child Health. 2019;24(1):e33-e39. https://doi.org/10.1093/pch/pxy072

14. Grunau RE, Craig KD. Neonatal facial coding system revised: training manual. Vancouver: Early Human Experience Unit; 2010.

15. Shabani F, Nayari ND, Karimi R, Zarei K, Chehraizi M. Effects of music therapy on pain responses induced by blood sampling in premature infants: a randomized cross-over trial. Iran J Nurs Midwifery Res. 2016;21:391-6. https://doi.org/10.4103/1735-9066.185581

16. Azarmnejad E, Sarhangi F, Javadi, M, Rejeh N. The Effect of Mother's Voice on Arterial Blood Sampling Induced Pain in Neonates Hospitalized in Neonate Intensive Care Unit. Global Journal of Health Science. 2015; 7(6). https://doi.org/10.5539/gjhs.v7n6p198

17. Cavaiuolo C, Casani A, Di Manso G, Orfeo L. Effect of Mozart music on heel prick pain in preterm infants: a pilot randomized controlled trial. J Pediatr Neonat Individual Med. 2015;4(1):e040109. https://doi.org/10.7363/040109

18. Witt N, Coynor S, Edwards C, Bradshaw H. A guide to pain assessment and management in the neonate. Curr Emerg Hosp Med Rep. 2016;4:1-10. https://doi.org/10.1007/s40138-016-0089-y

19. Gonzalez RAC, Luque AT, Piedra CD, Vico FJ, Casal GB. Listening to relaxing music improves physiological responses in premature infants: a randomized controlled trial. 2018;18(1):58-69. https://doi.org/10.1097/ANC.0000000000000448

20. Alipour Z, Eskandari N, Tehran HA, Hossaini SKE, Sangi S. Effects of music on physiological and behavioral responses of premature infants: a randomized controlled trial. Complement Ther Clin Pract. 2013;19(3):128-32. https://doi.org/10.1016/j.ctcp.2013.02.007 